\title{
Embryonic stem cells differentiate into insulin-producing cells without selection of nestin-expressing cells
}

\author{
PRZEMYSLAW BLYSZCZUK ${ }^{1}$ CHRISTIAN ASBRAND², ALDO ROZZO³, GABRIELA KANIA ${ }^{1}$, LUC ST-ONGE², \\ MARJAN RUPNIK ${ }^{3}$ and ANNA M. WOBUS*,1 \\ ${ }^{1}$ In Vitro Differentiation Group, Institute of Plant Genetics and Crop Plant Research (IPK), Gatersleben, ${ }^{2}$ DeveloGen AG, Göttingen and \\ ${ }^{3}$ European Neuroscience Institute, Göttingen, Germany
}

\begin{abstract}
We present a new strategy for the differentiation of embryonic stem (ES) cells into insulin-producing cells via a multi-step process without selection and induction of nestin-positive cells. During ES cell differentiation, transcript levels of genes characteristic of early and mature beta cells including Pdx1, Pax4, insulin and islet amyloid pancreatic peptide are up regulated. Islet-like clusters are characterized by expression of C-peptide, insulin and partially cytokeratin 19 as well as by ion channel activity similar to that found in embryonic beta cells. Cells of islet-like clusters show glucose-dependent insulin release at terminal stage. At an intermediate stage, nestin is partially coexpressed with C-peptide and cytokeratin 19, whereas islet-like clusters at the terminal stage are nestin-negative. We conclude that expression of nestin and cytokeratin 19 is a normal property of ES cells preceding differentiation into C-peptide/insulin-producing cells without any selection for nestin-positive phenotypes.
\end{abstract}

KEY WORDS: mouse embryonic stem cell, differentiation, C-peptide, insulin-producing cell, nestin

\section{Introduction}

A potential source of transplantable cells for the treatment of diabetes are embryonic stem (ES) cells, which have an almost unlimited proliferation capacity, while retaining the potential to differentiate in vitro into cells of all three primary germ layers [for review, see (Czyz etal., 2003)]. Insulin-expressing cells have been generated from mouse (Soria etal., 2000; Leon-Quinto et al., 2004) and human (Assady et al., 2001) ES cells. Insulin-positive cells were also derived from mouse ES cells via selection of progenitor cells expressing the intermediate filament (IF) protein nestin (Lumelsky et al., 2001). However, it was recently suggested that insulin-positive cells derived from ES cells absorbed and concentrated the hormone from the medium rather than producing insulin (Rajagopal et al., 2003; Hansson et al., 2004); whereas other reports described ES cell differentiation into transplantable insulinproducing cells via nestin-positive cells by treatment with a phosphoinositide 3-kinase inhibitor (Hori et al., 2002) and by Pax4 transgene expression (Blyszczuk et al., 2003), respectively.

In vivo, nestin expression during pancreas development was only detected in mesenchymal and not in pancreatic epithelial cells (Selander and Edlund, 2002). Whereas cytokeratin 19 (CK19) was found to be expressed in the developing pancreas and in pancreatic duct cells, where potential pancreatic stem cells reside (Bouwens, 1998; Bonner-Weir et al., 2000; Brembeck et al., 2001), nestin was not identified as a specific marker of betacell precursors (Humphrey etal., 2003). However, after cultivation of pancreatic islets in vitro, nestin-positive cells were detected (Zulewski et al., 2001). The controversial findings substantiated our studies to characterize nestin and CK 19 expression during differentiation of ES cells into C-peptide/insulin-positive cells and To this aim, we established a new protocol for the differentiation of ES cells into the pancreatic lineage without pre-selection of nestin-positive cells, determined the abundance of C-peptide-, CK19- and nestin-positive cells and analyzed the functional capacity of differentiated cells. We found a co-expression of nestin with C-peptide and CK19 at intermediate stage, but not in

Abbreviations used in this paper: EB, embryoid body; ES, embryonic stem; bFGF, basic fibroblast growth factor; CK, cytokeratin; DMEM, Dulbecco's modified Eagle's medium; ELISA, enzyme linked immunosorbent assay; FCS, fetal calf serum; IAPP, islet amyloid polypeptide; IF, intermediate filament; IMDM, Iscove's modified Dulbecco's medium; ITSFn, insulin, transferrin, selenium, fibronectin; PBS, phosphate buffered saline; PFA, paraformaldehyde; RT-PCR, reverse transcriptase-polymerase chain reaction; SEM, standard error of the mean; STZ, streptozotocin; wt, wild type.

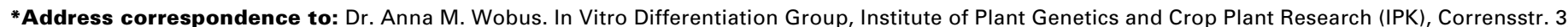
D-06466 Gatersleben, Germany. Fax: +49-39482-5481. e-mail: wobusam@ipk-gatersleben.de
} 
islet-like clusters. Our data let us to conclude that nestin and CK 19 are involved in pancreatic differentiation in vitro and that cells differentiating along these pathways acquire some characteristics of pancreatic beta-like cells.

\section{Results}

Transcript levels of pancreatic genes are upregulated in ESderived cells differentiating into insulin-producing cells without selecting nestin-positive cells

Our new differentiation protocol for the generation of ESderived insulin-producing cells (Fig. 1C) includes the spontaneous generation of multi-lineage progenitor cells and their differentiation induction into islet-like clusters. No selection for nestinpositive cells is performed at any time of ES cell differentiation. In brief, ES cells were cultured in 'hanging drops' and in suspension for 5 days to form embryoid bodies (EBs) followed by 9 days culture after EB plating $(=5+9 \mathrm{~d})$ for differentiation into cells representing derivatives of all three primary germ layers [for details see (Rohwedel etal., 2001; Wobus etal., 2002; Blyszczuk et al., 2003)]. At this stage, cells were re-plated onto poly-Lornithine/laminin-coated culture dishes [see (Rolletschek et al., 2001)] into a 'pancreatic differentiation medium' (= N2 medium + nicotinamide, NA, see Fig. $1 \mathrm{C}$ ) and cultured until stage 5+28d. Cells were analyzed for pancreatic differentiation markers at stages $5+9 d, 5+16 d$ and $5+28 d$. In the present study and in previous reports (Lumelsky et al., 2001; Hori et al., 2002; Moritoh et al., 2003; Rajagopal et al., 2003; Blyszczuk et al., 2003), the same 'pancreatic differentiation medium' was used to induce pancreatic differentiation. However, in contrast to Lumelsky et al. (2001), our new protocol avoids the enrichment of nestin-positive cells in ITSFn medium [see Lee et al. (2000), used also in our former study (Blyszczuk et al., 2003); see Fig. $1 \mathrm{~B}]$ and the proliferation induction of nestin-positive cells by bFGF [according to Lumelsky et al. (2001); compare Fig. 1 A,C]. Therefore, our new protocol allows the characterization of cells during pancreatic differentiation of ES cells without enrichment of specific subpopulations that may affect commitment and differentiation into the pancreatic lineage.

Employing RT-PCR and immunofluorescence techniques we show that by applying our new protocol ES cells differentiate into the pancreatic lineage. Upon induction of pancreatic differentiation at day $5+9$, development into pancreatic endocrine cells is demonstrated by the up-regulation of Pdx1, Pax4, insulin and IAPP mRNA levels (Fig. 2A) resulting in the formation of self-assembling islet-like clusters, which are labelled by insulin and C-peptide following differentiation (Fig. 2B).

$P d x 1$ transcripts were detected at low level at day $5+9$, showed no $P d x 1$ signals at the intermediate stage $(5+16 d)$, but increased significantly at the terminal stage $(5+28 d)$. Lack or low Pdx1 expression at early stages in vitro confirms also recent findings which show that $P d x 1$ is not required for the induction of pancreatic differentiation from ES cells in vitro (Moritoh et al., 2003); although it plays a key role in early pancreas development (Jonsson et al., 1994) as well as in terminal differentiation

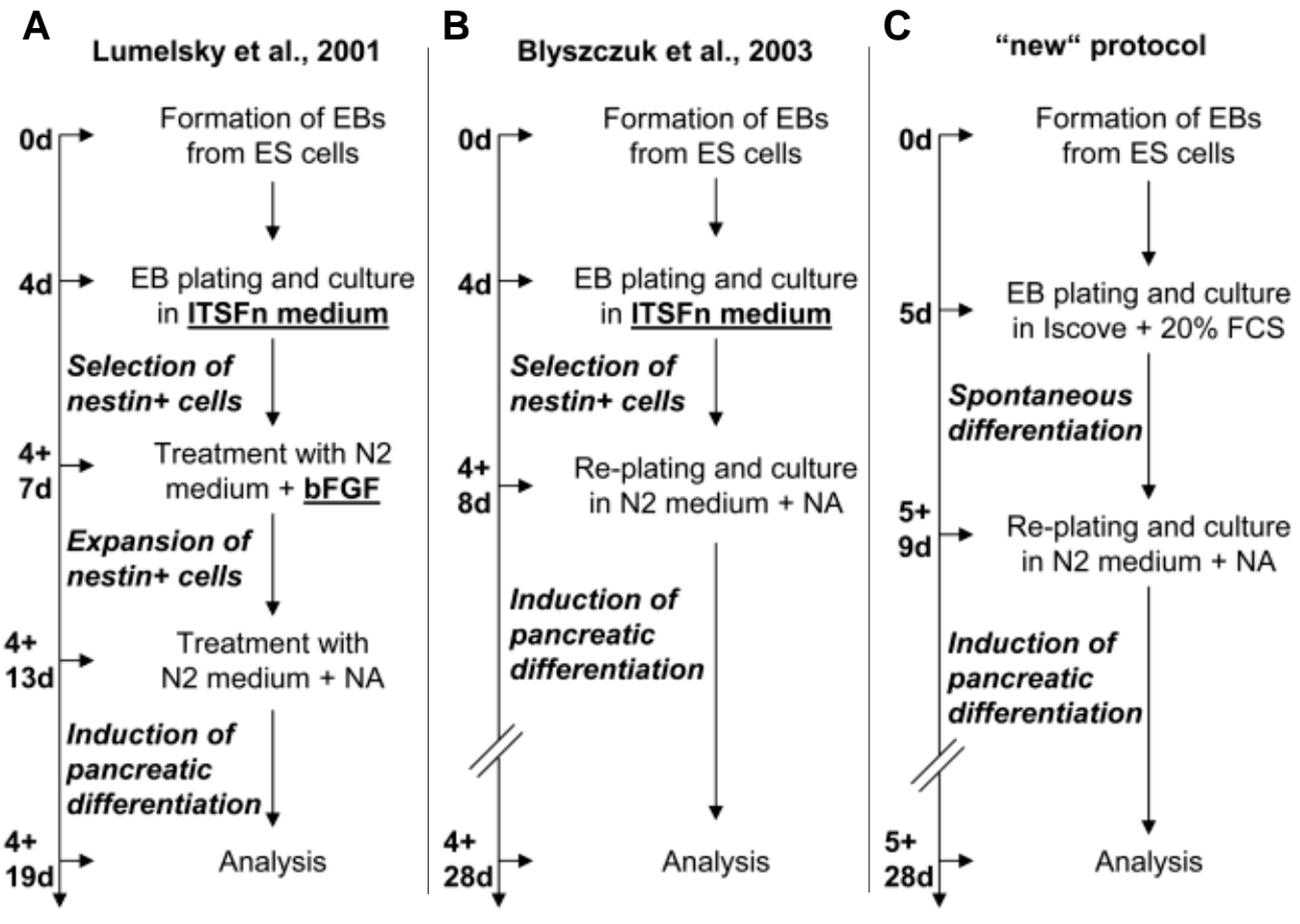

Fig. 1. Schematic representation of protocols used to generate functional islet-like clusters from ES cells in vitro. (A-C) The protocols developed by (A) Lumelsky et al. (2001), (B) that employed in our former study [Blyszczuk et al. (2003)] and (C) that of the present study ("new" protocol), differ in the generation of progenitor cells, but all protocols use the same pancreatic differentiation medium. All protocols generate progenitor cells from ES cells via EB formation, but protocols (A) and (B) enrich nestin-positive cells in ITSFn supplemented medium, whereas according to the "new" protocol (C), EB-derived cells differentiate spontaneously. A further expansion of nestin-positive cells by bFGF is performed only in protocol (A), whereas in methods $(B)$ and $(C)$ the selective expansion of nestin-positive cells is omitted. According to our "new" protocol (C), a progenitor population representing cells of all three primary lineages is generated by spontaneous differentiation of ES cells followed by the induction of pancreatic differentiation. 
and functionality of pancreatic cells (Ahlgren et al., 1998).

Another evidence for the activation of a pancreatic differentiation program in ES cells by following our protocol, is the up-regulation of insulin and IAPP, a peptide almost exclusively expressed in beta-cells and co-secreted with insulin (Fehmann et al., 1990).

Pax4 transcripts were up regulated upon induction of pancreatic differentiation at $5+16 \mathrm{~d}$ and $5+28 \mathrm{~d}$. In vivo, Pax4 is essential for proper beta-cell development (SosaPineda etal., 1997) and its expression is restricted to the endocrine progenitor cell fate (Dohrmann et al., 2000). We have recently reported that constitutive expression of Pax4 in ES cells significantly promotes pancreatic differentiation (Blyszczuk et al., 2003).

To test whether ES-derived insulin-positive cells produce or only absorbed insulin from the medium [see (Rajagopal et al., 2003)], we analysed co-expression of insulin and C-peptide. The formation of C-peptide (part of proinsulin when converted into insulin) demonstrates de novo insulin production and excludes those cells that only concentrate insulin from the medium. The number of C-peptide-labelled cells increased after induction of pancreatic differentiation up to about 3 fold at terminal stage $(5+28 d$, Table 1$)$. A high fraction of insulin-positive cells (about 85\%) co-expressed C-peptide (see arrowheads in Fig. 2B) and were organized in islet-like clusters at terminal stage of $5+28 d$ (Fig. 2B), whereas only a low fraction (about 10-15\%) of cells were labeled by insulin, but not by C-peptide (see arrows in Fig. 2B). These cells were eventually characterized by small, condensed nuclei suggesting an apoptotic pathway as described (Rajagopal et al., 2003). In contrast to Rajagopal et al. (2003), we showed coexpression of insulin and C-peptide in most of the ES-derived cells indicating de novo insulin production and, as demonstrated in Fig. $2 \mathrm{~A}$, high insulin mRNA levels were determined at terminal stages.

\section{Nestin is coexpressed in C-peptide-positive cells after induc- tion of pancreatic differentiation}

To answer the question, whether nestin is involved in the generation of insulin-producing cells during ES cell differentiation,

TABLE 1

NUMBER OF NESTIN-, C-PEPTIDE-, CYTOKERATIN (CK) 19 , CARBONIC ANHYDRASE II- (CARB. ANH. II), DESMIN- AND ISLET-1 (ISL-1)-IMMUNOREACTIVE CELLS AS A PERCENTAGE OF HOECHST 33342-LABELLED CELLS DURING PANCREATIC DIFFERENTIATION OF R1 ES CELLS

Stage

\begin{tabular}{lccccccc}
\hline & $\begin{array}{c}\text { Nestin } \\
(\%)\end{array}$ & $\begin{array}{c}\text { C-peptide } \\
(\%)\end{array}$ & $\begin{array}{c}\text { CK19 (\%) } \\
\text { MeOH:Ac }\end{array}$ & $\begin{array}{c}\text { CK19 (\%) } \\
\text { 4\% PFA }\end{array}$ & $\begin{array}{c}\text { Carb. anh. II } \\
(\%)\end{array}$ & $\begin{array}{c}\text { Desmin } \\
(\%)\end{array}$ & $\begin{array}{c}\text { Isl-1 } \\
(\%)\end{array}$ \\
& & & & & & & \\
$5+9 d$ & $23.7 \pm 5.3$ & $9.9 \pm 1.7$ & $8 \pm 2.2$ & $<1.0$ & n.d. & $32.5 \pm 5.9$ & $3.1 \pm 1.9$ \\
$5+16 d$ & $21.7 \pm 4.8$ & $32.4 \pm 3.3$ & $<1.0$ & $31.6 \pm 6.2$ & $32.2 \pm 4.5$ & $20.1 \pm 3.7$ & $15.4 \pm 7.1$ \\
$5+28 d$ & $21.4 \pm 4.3$ & $26.6 \pm 7.7$ & $<1.0$ & $21.3 \pm 1.3$ & $26.6 \pm 8.0$ & n.d. & $8.7 \pm 2.9$ \\
\hline
\end{tabular}

Cells of each immunopositive fractions partially overlap. Differentiation stage $5+9 \mathrm{~d}$ represents spontaneous differentiation, whereas stages $5+16 \mathrm{~d}$ and $5+28 \mathrm{~d}$ represent 7 and 19 days, respectively, after induction of pancreatic differentiation. Immunostaining for CK19 was performed separately after fixation with methanol-acetone (MeOH:Ac) and $4 \%$ paraformaldehyde (PFA). Each value represents mean $\pm S E M$, n.d. $=$ not determined, $n \geq 3$ experiments.
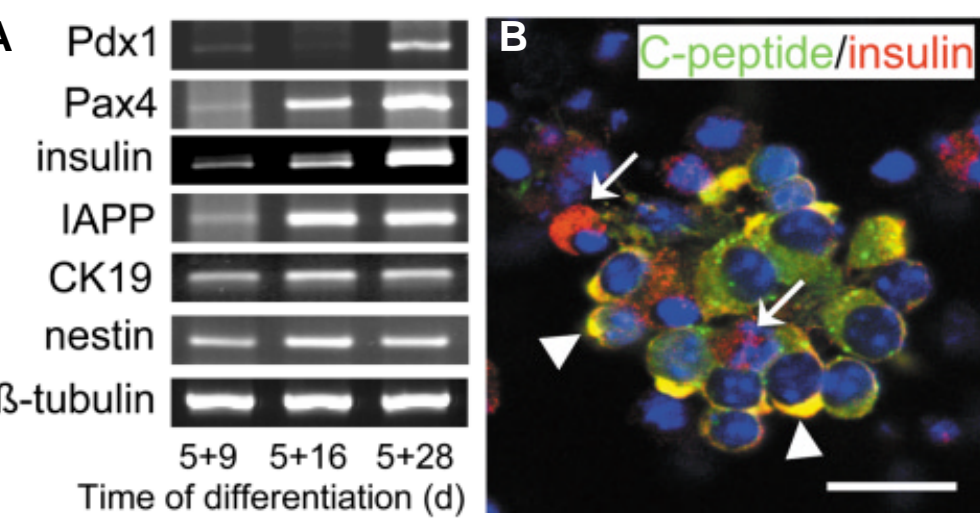

Time of differentiation (d)

Fig. 2. Transcript levels and an islet-like cluster after pancreatic differentiaion of ES cells. (A) mRNA levels of Pdx1, Pax4, insulin, IAPP, cytokeratin (CK)19, estin and $\beta$-tubulin (housekeeping) genes of ES-derived cells during in vitro differentiation are shown at stages $5+9 d, 5+16 d$ and $5+28 d$. (B) Immunofluores tage of differentiation $(5+28 d)$. Arrowheads indicate insulin/C-peptide co-expresswith small and condensed nuclei suggesting apoptosis. Nuclei are labelled by chst 33342. Bar, $20 \mu \mathrm{m}$.

we analysed transcript abundance and co-localization of nestin and $C$-peptide by immunostaining at stages $5+9 d, 5+16 d$ and $5+28 d$. Nestin mRNA levels were detected at all stages (see Fig. $2 \mathrm{~A}$ ) and nestin-positive cells were present at constant level during differentiation between day 5+9 and 5+28 (Table 1).

A high co-expression of nestin and C-peptide was found exclusively at stage $5+16 \mathrm{~d}$ (Fig. 3G, Tables $2 \mathrm{~A}$ and $2 \mathrm{~B}$ ). Continued differentiation up to $5+28 \mathrm{~d}$ resulted in $\mathrm{C}$-peptide expressing islet-like clusters negative for nestin (Fig. 3K). Our findings demonstrate that nestin is transiently involved in ES-derived pancreatic differentiation.

To determine, if nestin-positive cells co-express desmin [another IF protein detected in mesenchymal cells and in pancreatic stellate cells, see (Lardon et al., 2002)] and whether such cells are involved in pancreatic differentiation of ES cells, we performed double immunostaining with desmin- and nestin-specific antibodies. Partial co-expression of nestin and desmin was detected at

TABLE 2

\section{DOUBLE IMMUNOFLUORESCENCE ANALYSIS OF ES-DERIVED INTERMEDIATE CELL STAGES REPRESENTING NESTIN (A) AND C-PEPTIDE (B) CELL POPULATIONS}

(A)

\begin{tabular}{lcccc} 
Stage & Nestin (\%) & C-peptide (\%) & Isl-1 (\%) & Desmin (\%) \\
\hline $5+9 d$ & 100 & $34.1 \pm 14.5$ & $1.0 \pm 0.9$ & $46.1 \pm 10.3$ \\
$5+16 d$ & 100 & $83.9 \pm 7.1$ & $60.4 \pm 13.7$ & $15.0 \pm 6.2$ \\
$5+28 d$ & 100 & $41.0 \pm 6.7$ & $8.5 \pm 3.6$ & n.d.
\end{tabular}

Number (in \%) of C-peptide-, Islet-1 (Isl-1)- and desmin-labelled cells determined within the fraction of nestin-positive cells (nestin-positive cells were set to $100 \%$ ). Each value represents mean \pm SEM n.d. $=$ not determined, $n \geq 3$ experiments.

(B)

\begin{tabular}{lcccc} 
Stage & C-peptide (\%) & Nestin (\%) & Carb. anh. II (\%) & CK19 (\%) \\
\hline $5+16 d$ & 100 & $82.2 \pm 6.9$ & $99.8 \pm 0.3$ & $97.6 \pm 0.8$ \\
$5+28 d$ & 100 & $30.7 \pm 6.7$ & $99.7 \pm 0.2$ & $73.0 \pm 1.4$ \\
\hline
\end{tabular}

Number (in \%) of nestin-, carbonic anhydrase II (carb. anh. II)- and cytokeratin (CK) 19-labeled cells as a percentage of the fraction of C-peptide-positive cells (C-peptide-positive cells were set to $100 \%)$. Each value represents mean \pm SEM, $n \geq 3$ experiments. 

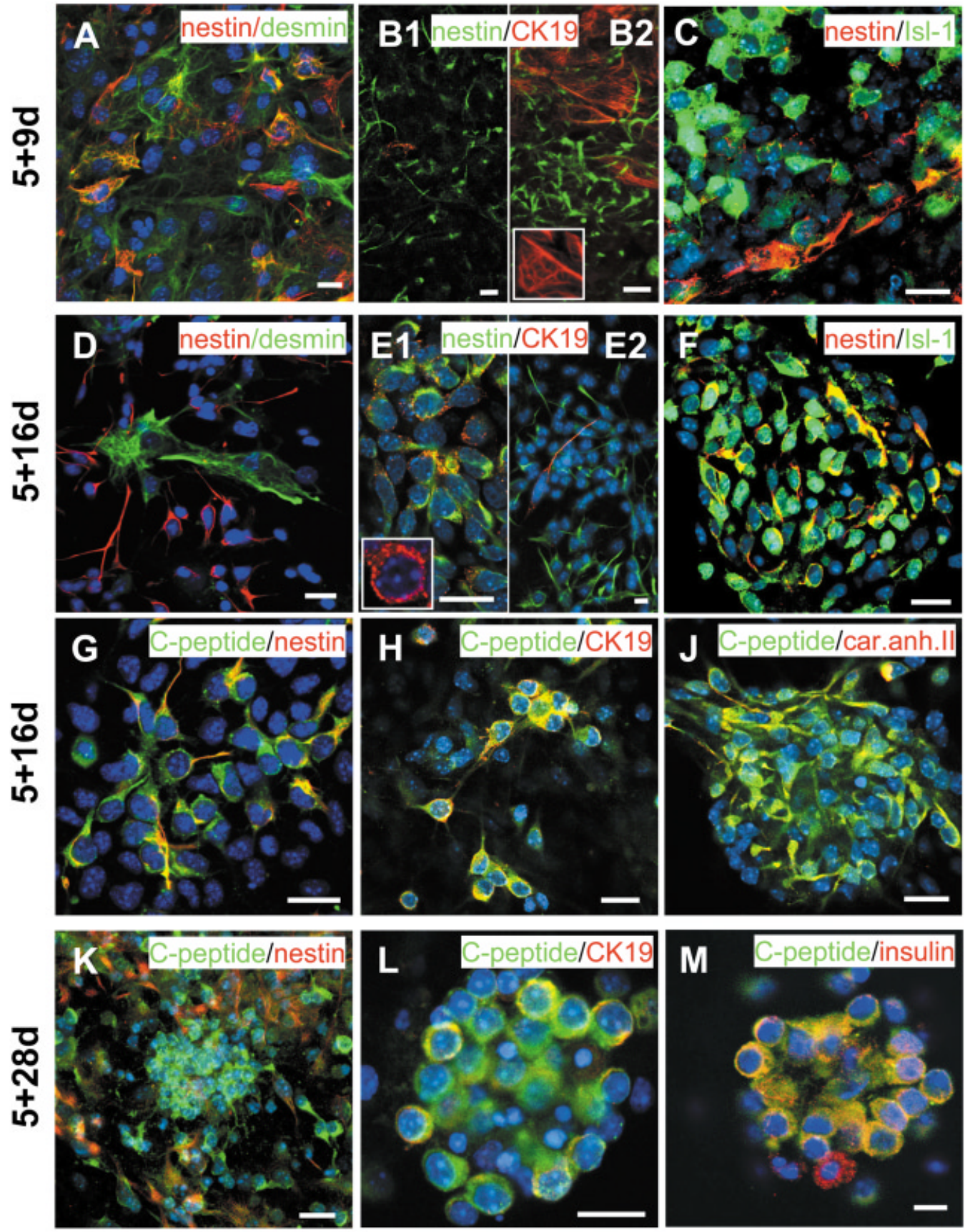

Fig. 3. Double-immunofluorescence analysis of ES-derived cells at intermediate and terminal stages following pancreatic differentiation. (A-F) Analysis of nestin-labelled cells for co-expression with desmin $(\mathbf{A}, \mathbf{D})$, cytokeratin (CK) 19 [fixed with paraformaldehyde, (B1, E1) and methanol: acetone (B2, E2) ], Isl-1 (C,F), both fixed with paraformaldehyde, at early $(5+9 d, A-C)$ and intermediate $(5+16 d$, $D-F)$ stages of differentiation. Note that not all cells show nuclear Isl-1 labelling in (3F). (G-M) Immunofluorescence analysis of C-peptide-labelled cells for co-expression with nestin $(\mathbf{G}, \mathbf{K})$, CK19 [fixed with paraformaldehyde, $\mathbf{( H , L ) ] ~ c a r b o n i c ~}$ anhydrase /I (carb. anh. II, (J)) and insulin (M) at intermediate $(5+16 d$, G-J) and terminal $(5+28 d, K-M)$ stages of differentiation. Quantitative analysis of the immunofluorescence signals is presented in Tables 1 and 2, respectively. Nuclei are labelled by Hoechst 33342. Bar, 20 $\mu m$.

stage $5+9 d$ (Fig. 3A). Whereas upon induction of pancreatic differentiation, only a low cell fraction co-expressed nestin and desmin (Table 2A), the remaining nestin- and desmin-positive cells showed clear differences in the morphology (see Fig. 3D). Moreover, the total number of desmin-positive cells decreased after induction of pancreatic differentiation (see Table 1). These findings suggest that desmin is not involved in the terminal differentiation of pancreatic cells.

\section{Cytokeratin 19 is expressed during ES-derived pancreatic differentiation, but is not organized into filaments}

Because cytokeratin 19 (CK19) is expressed in developing pancreatic epithelium, where the definitive pancreatic progenitor reside and in adult pancreatic duct cells (Brembeck et al., 2001), where potential pancreatic stem cells may be located (Bouwens, 1998; Bonner-Weir et al., 2000; Ramiya et al., 2000), next we asked whether CK19 is involved in the generation of C-peptide/ insulin-positive cells during ES cell differentiation.

CK19 transcripts were detected at all stages of pancreatic differentiation (see Fig. 2A) suggesting the involvement of CK19 during ES cell differentiation. However, immunofluorescence analysis demonstrated specific differences in the organization of CK19-positive intermediate filaments by applying different fixation methods. Conventional fixation with methanol/ acetone was suitable for detection of intermediate filaments (Fig. 3 B2, E2) and we found a low fraction of CK19-positive cells at stage $5+9 d$, 
A
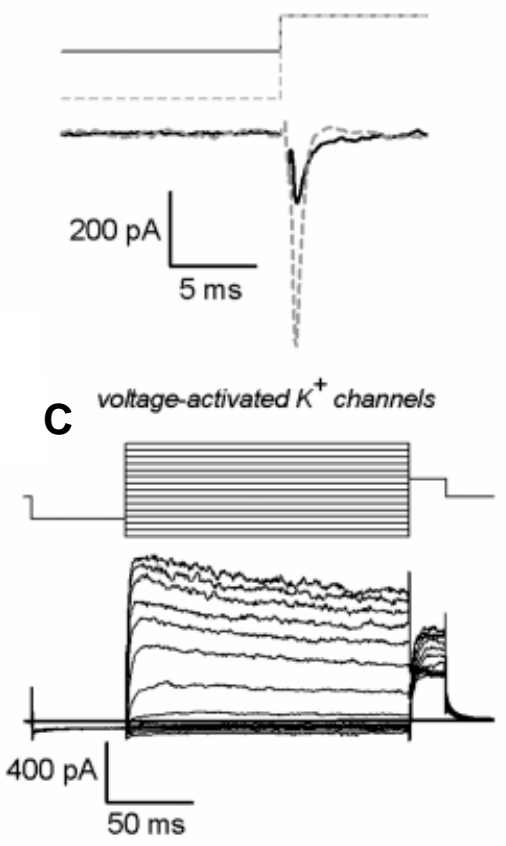

B

B ATP-sensitive $K^{+}$channels

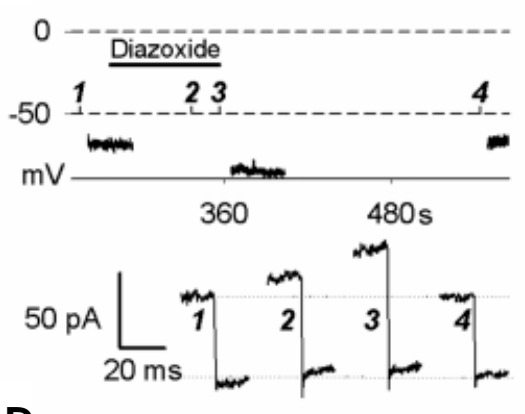

D

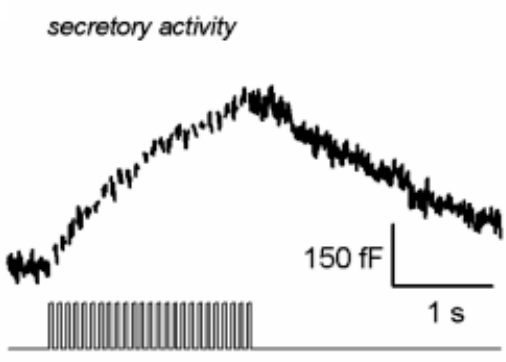

Fig. 4. Results of whole-cell patch-clamp analysis of wt and Pax4+ ES-derived cells from islet-like clusters at stage $5+30 \mathrm{~d}$. (A) Inactivation of voltage-activated $\mathrm{Na}^{+}$currents at sub-physiological membrane potentials. Depolarisation to $-20 \mathrm{mV}$ from $-75 \mathrm{mV}$ and -150 $m V$ generated inward currents of 210 and 640 $p A$, respectively. (B) Voltage-activated $K^{+}$currents induced by a family of depolarising pulses in steps of $15 \mathrm{mV}$. (C) Current-clamp recording of a cell treated with diazoxide (100 vM). At points indicated by numbers, $\mathrm{K}^{+}$conductance was measured using square hyper-polarization from $-60 \mathrm{mV}$ to $-110 \mathrm{mV}$. Cell hyper-polarization during diazoxide superfusion is associated with significant increase in membrane conductance. (D) Typical increase in membrane capacitance triggered by a train of depolarising pulses from $-80 \mathrm{mV}$ to $+10 \mathrm{mV}$ indicates $\mathrm{Ca}^{2+}$-dependent exocytosis. whereas after pancreatic differentiation induction $(5+16 d)$, almost no CK19-positive cells were found (Table 1). In addition, the cells showed no co-expression of CK19 and nestin at early $(5+9 d)$ and intermediate $(5+16 \mathrm{~d})$ stages (Fig. 3 B2, E2). After fixation with $4 \%$ paraformaldehyde, CK19-labelled dot-like structures were detected in the cytoplasm of a few cells at stage $5+9 d$ (Fig. 3B1), however upon induction of pancreatic differentiation (stage $5+16 \mathrm{~d}$ ), CK19 labeling was found in $31.6 \%$ cells (Table 1 ) and was highly co-expressed with nestin (Fig. 3E1, Table 2A). After continued differentiation (stage $5+28 d$ ), the number of CK19positive cells was reduced $(21.3 \%$, Table 1$)$. Similar dot-like structures were described for another IF protein, vimentin, after fixation with paraformaldehyde (Prahlad et al., 1998). We conclude that the different fixation properties reflect conformational changes (intermediate filaments versus dot-like structures) of the IF proteins during differentiation.

Next, we determined, whether CK19-positive cells are present in the fraction of C-peptide-positive cells that are involved in the formation of islet-like clusters in vitro. Double immunofluorescence analysis showed that $97.6 \%(5+16 d)$ and $73 \%(5+28 d)$ of C-peptide positive cells co-expressed CK19 (Fig. 3 H,L, Tab. 2B). These data suggest that CK19 protein is abundant during pancreatic differentiation, but the protein is not organized in intermediate filaments. The decrease of CK19-labeling in C-peptide-positive cells at terminal stage may indicate a certain maturation of ESderived cells during differentiation. This would be in agreement with the finding that mature beta cells in vivo are negative for CK19 (Bouwens et al., 1997).

\section{Islet-1 is expressed in ES-derived progenitor cells}

The data presented so far have shown that nestin and CK19 are partially and transiently co-expressed in C-peptide/insulinproducing cells. Next, we asked whether IsI-1, a LIM homeodomain protein that controls cell-fate decisions required for the differentiation of islet cells (Ahlgren et al., 1997) is expressed during ES cell differentiation. We found only a low fraction of Isl-1-positive cells at the early differentiation stage of $5+9 d$ and almost no cells co-expressed Isl-1 and nestin (Fig. 3C, Tables 1 and 2A). However, after induction of pancreatic differentiation, $60.4 \%$ of nestinpositive cells co-expressed IsI-1 and only occasionally cells positive for Isl-1 and negative for nestin were found (Table 2A). Continued differentiation resulted in a decreased number of Isl-1positive cells at stage $5+28 d$ (Table 1 ). These findings suggest that IsI-1 is transiently expressed in the nestin-positive subpopulation of committed pancreatic cells expressing nestin and Cpeptide (at stage $5+16 \mathrm{~d}$ ). The data are in agreement with recent findings, which showed that Isl-1 expression is restricted to a specific subpopulation of pancreatic stem cells during pancreas development (Chiang and Melton, 2003). Our immunofluorescence analyses suggest that Isl-1 is activated in nestin-positive cells committed to the pancreatic lineage, because a remarkable number of cells co-expressing Isl-1 and nestin were detected at day $5+16 d$ (see Fig. 3F, Table 2A).

\section{Carbonic anhydrase II is involved in pancreatic differentia- tion in vitro}

Another protein expressed in pancreatic duct cells is carbonic anhydrase II (Githens et al., 1992). We investigated the abundance of carbonic anhydrase II in C-peptide-positive ES-derived cells and found that upon induction of pancreatic differentiation nearly all C-peptide-positive cells co-expressed carbonic anhydrase II (Fig. 3J, Table 3). In vivo, mature pancreatic beta-cells express carbonic anhydrase $\mathrm{V}$ instead of carbonic anhydrase II (Parkkila et al., 1998) suggesting that in vitro generated ESderived cells represent an immature pancreatic cell population, rather than definitive mature pancreatic beta-cells. 


\section{Insulin-producing cells functionally express beta-cell-spe- cific properties}

Next, we investigated functional properties of ES-derived wt cells in comparison to ES cells constitutively expressing Pax4 (Pax4+). We have reported that Pax4+ cells promote pancreatic differentiation (Blyszczuk et al., 2003) and confirmed this by applying our new differentiation protocol. Pax4+ cells formed Cpeptide-positive islet-like clusters similar as described for wt cells, but showed a higher level of C-peptide-labelled cells (not shown). The functional status of both cell lines was analysed by electrophysiological studies using the patch-clamp technique on cells found within islet-like clusters and by ELISA. Electrophysiological measurements showed that ES-derived pancreatic cells were excitable and revealed characteristic properties of beta-cells with respect to voltage-activated $\mathrm{Na}^{+}$and $\mathrm{K}^{+}$currents (Fig. $4 \mathrm{~A}, \mathrm{~B}$, Table 3). In some Pax4+ cells, $\mathrm{K}_{\mathrm{ATP}}$ channels were responsive to the specific channel opener diazoxide (Fig. 4C, Table 3) and secretory activity was induced via activation of voltage-activated $\mathrm{Ca}^{2+}$ channels (Fig. 4D, Table 3). The characteristics of voltageactivated $\mathrm{Na}^{+}$channel inactivation, voltage-activated $\mathrm{K}^{+}$channel properties and the $\mathrm{Ca}^{2+}$-dependent secretory activity in ESderived pancreatic cells (Table 3 ) suggest a similarity of ESderived pancreatic cells to embryonic beta-cells. The presence of cells responsive to $\mathrm{K}_{\text {ATP }}$ channel agonists and glucose-induced secretory activity of Pax4+ES-derived cells represent a developmentally advanced status in comparison to wt cells.

To further determine the functional status of insulin-producing cells, we analyzed glucose-dependent insulin release by ELISA. We found that both cell lines released higher insulin levels in response to $27.7 \mathrm{mM}$ glucose compared to $5.5 \mathrm{mM}$ glucose (Fig. $5 A)$. Pax4+ cells showed higher insulin levels, but the ratio of released/intracellular insulin level was similar for wt and Pax4+ cells (Fig. 5B). The increased intracellular insulin level and insulin release of $\mathrm{Pax} 4+$ cells in comparison to wt cells correlated with higher levels of C-peptide expression in Pax4+ cells.

\section{Insulin-secreting cells generated from Pax4+ cells normalize blood glucose levels in diabetic mice}

We tested the in vivo potential of ES-derived insulin-producing cells by transplanting differentiated (stage 5+28d) wt and Pax4+ cells $\left(n=4-6 \times 10^{6}\right)$, respectively, under the kidney capsule and into the spleen of streptozotocin (STZ)-induced diabetic mice. Cells were transplanted into hyperglycemic mice with blood glucose levels above $15 \mathrm{mM}$ and blood glucose levels and body weight were monitored over a period of about 5 weeks. Mice transplanted with wt cells and sham-transplanted control animals remained hyperglycemic at levels of about 25- $30 \mathrm{mM}$ (Fig. 6A) and suffered from diabetic weight loss (Fig. 6B). Animals transplanted with Pax4+ cells reduced blood glucose levels 2 weeks after transplantation and attained a normal glycemia status by 5 weeks (Fig. 6A). Weight loss was attenuated in mice engrafted with Pax4+ cells (Fig. 6B).

In two mice engrafted with Pax4+ cells, partial graft removal by unilateral nephrectomy was performed 26 days after transplantation. These mice showed an increase in blood glucose level in contrast to non-nephrectomized mice (Fig. 6A). Some mice transplanted either with wt or Pax4+ cells developed tumours.

\section{Discussion}

The application of a new protocol to generate insulin-producing cells without selecting for nestin-positive cells enabled the formation of islet-like clusters that express Pdx1, Pax4, IAPP and insulin. The cells released insulin in response to glucose, showed beta-cell-specific ion channel activity and are able to rescue diabetes in an animal model. C-peptide expression in insulinproducing cells and glucose-dependent insulin release presents evidence that the cells produced and released insulin, whereas only a low fraction of cells may uptake insulin from the medium. We show that the differentiation of ES cells without selection of nestin-positive cells generates islet-like clusters. In principle, the formation of insulin-producing cells was described by several authors (Lumelsky et al., 2001; Hori et al., 2002; Blyszczuk et al., 2003; Moritoh et al., 2003; Miyazaki et al., 2004), however, the specific properties of ES-derived pancreatic cells may be different. It was presented that insulin-positive cells derived from ES cells (via selecting nestin-positive progenitors!) concentrate insulin from the medium (Rajagopal et al., 2003; Sipione et al., 2004) and/or that the differentiated cells show an artifactual insulin release (Hansson et al., 2004). These findings would suggest that pancreatic differentiation from ES-derived nestinpositive cells generated by selective culture in ITSFn medium and in the presence of bFGF is irreproducible and shows no or very limited evidence of pancreatic differentiation.

Our data show that the selection of nestin-positive cells with ITSFn and bFGF is neither obligatory nor profitable for successful

\begin{tabular}{c|c|c|c}
$\begin{array}{c}\text { Cell } \\
\text { line }\end{array}$ & $\begin{array}{c}\text { Intracellular } \\
\text { insulin }(\mathrm{ng} / \mathrm{mg} \\
\text { protein) }\end{array}$ & $\begin{array}{c}\text { Released insulin } \\
(\mathrm{ng} / \mathrm{mg} \text { protein) at } \\
5.5 \mathrm{mM} \text { glucose }\end{array}$ & $\begin{array}{c}\text { Released insulin } \\
(\mathrm{ng} / \mathrm{mg} \text { protein) at } \\
27.7 \mathrm{mM} \text { glucose }\end{array}$ \\
\hline wt & $38.1 \pm 4.7$ & $6.1 \pm 1.3$ & $8.6 \pm 1.0$ \\
\hline $\mathrm{Pax4}^{+}$ & $168.0 \pm 28.5$ & $17.3 \pm 2.9$ & $27.0 \pm 3.2$
\end{tabular}

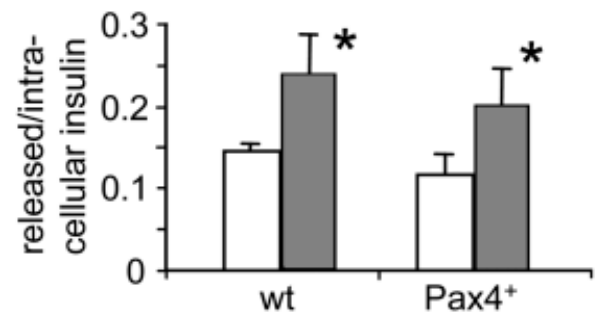

Fig. 5. Determination of insulin levels in ES-derived cells after pancreatic induction by ELISA. (A) Levels of intracellular and released insulin in response to $5.5 \mathrm{mM}$ and $27.7 \mathrm{mM}$ glucose, respectively, determined after $15 \mathrm{~min}$ of static incubation of wt and Pax4+ES-derived cells at stage $5+28 d$. (B) Representation of glucose-dependent insulin release by the ratio of secreted and intracellular insulin levels. Each value represents mean \pm SEM. Statistical significance was tested by the Student $t$ test: ${ }^{*}, P<0.05$. 


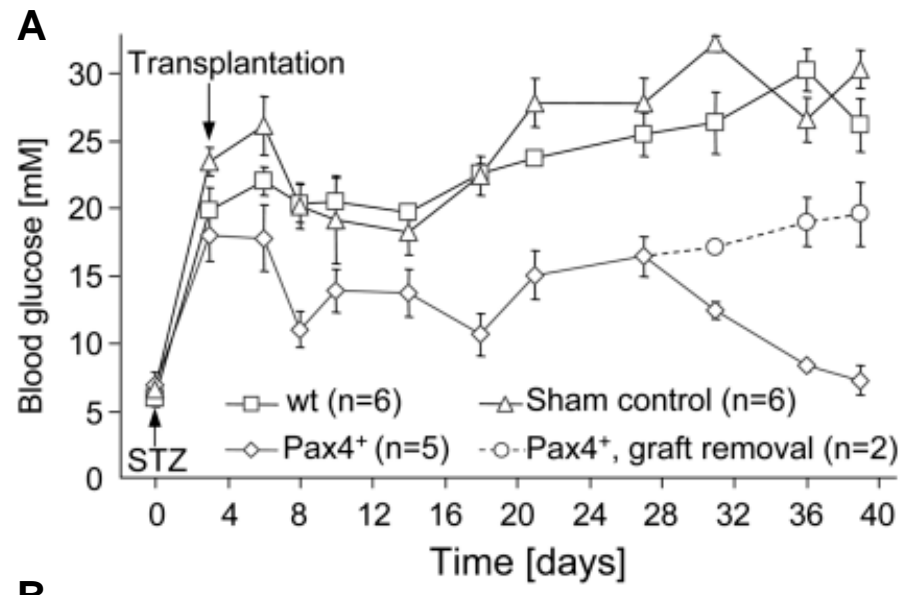

B

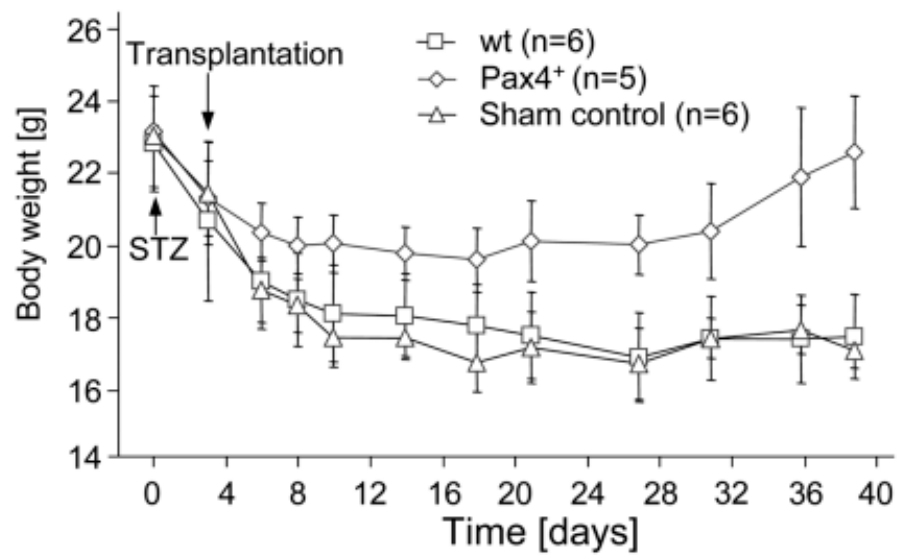

Fig. 6. Transplantation of wt and Pax4+ ES-derived cells at stage $5+28 d$ into STZ-treated diabetic mice and body weight of animals after transplantation. (A) Non-fasted blood glucose levels decreased in animals transplanted with Pax4+ insulin-producing cells as compared to animals receiving wt cells or sham transplants. In two mice transplanted by Pax4+ cells, unilateral nephrectomy was performed 26 days after transplantation to remove substantial parts of the graft. (B) Transplantation of Pax4+ES-derived cells ameliorates weight loss in diabetic mice in contrast to $w t$ cells and sham transplants.

pancreatic differentiation and does not promote the generation of specific pancreatic progenitors when applied to ES-derived cells. Previously, we have shown that the expansion of nestin-positive cells in the presence of bFGF is not required for the activation of pancreatic differentiation [(Blyszczuk et al., 2003), see Fig. 1B]. Therefore, in our present study, all selective steps, which support the growth and maintenance of nestin-positive cells, were avoided. Nevertheless, we show that nestin-expressing cells develop in vitro from ES cells following the induction of pancreatic differentiation.

Nestin is unequivocally accepted as a marker of neural progenitor cells, however the expression of nestin during pancreatic development remained controversial. Nestin was found in a subset of (insulin-negative) cells in pancreatic islets, suggesting that it might be a marker of pancreatic progenitor cells (Hunziker and Stein, 2000); however, Selander and Edlund did not find nestin in the pancreatic ductal epithelium (Selander and Edlund, 2002), where the potential progenitor cells reside (Bouwens,
1998; Bonner-Weir et al., 2000), instead, nestin was detected in mesenchymal cells, called pancreatic stellate cells (Lardon et al., 2002; Klein et al., 2003). Recent lineage-tracing studies using nestin regulatory elements to drive Cre-mediated activation of reporter genes in the developing pancreatic epithelium showed that nestin was transiently expressed in pancreatic epithelial progenitor cells in E10.5 mouse embryos (Esni et al., 2004). Later in development, nestin expressing cells were found to contribute mainly to the exocrine lineage (Delacour et al., 2004). In human pancreatic tissue, nestin was detected only at low levels in endocrine cells (Street et al., 2004). But, when cultivated in vitro, islet-derived cells express nestin, proliferate and differentiate into pancreatic endocrine phenotypes (Zulewski et al., 2001). Recent data confirmed that isolated and in vitro cultured adult pancreatic progenitors co-express neural and pancreatic markers including nestin (Seaberg et al., 2004). Here, we show that nestin is transiently expressed in ES-derived pancreatic cells. After induction of pancreatic differentiation, nestin is highly co-expressed with C-peptide at an intermediate stage, but at the terminal stage, $\mathrm{C}$-peptide positive clusters were negative for nestin. These results show that in vitro, nestin is transiently expressed in ESderived pancreatic progenitors committed to differentiation, similar to ES-derived neuronal [see Lee et al. (2000); Rolletschek et al. (2001)] and hepatic [see Kania et al. (2003)] lineages, but nestin is not detected in terminally differentiated pancreatic (as well as differentiated neuronal and hepatic) cell types. Moreover, before induction of pancreatic differentiation, a fraction of cells co-expressing nestin and desmin was found. Together, these data suggest that nestin expression in ES-derived progeny represents a property of multi-lineage progenitors characterized by immaturity and differentiation capacity (Wiese et al., 2004).

We demonstrate that ES-derived cells at the intermediate stage express C-peptide, CK19, carbonic anhydrase II and partially Isl-1. These properties suggest that the ES-derived progenitor population shows similarities with developing pancreatic betacells and pancreatic duct epithelial cells. CK19 is expressed in the duct epithelium in proposed pancreatic stem cells (Bouwens, 1998; Brembeck et al., 2001), but not in functional islets (Bouwens et al., 1997). In vitro, CK19 was not organized in intermediate filaments as demonstrated for pancreatic duct cells in vivo [see (Bouwens et al., 1995; Bouwens, 1998)]. Functional cytokeratins form heteropolymeric filaments composed of CKs of subclasses I and II (Herrmann and Aebi, 2000). Therefore, we may argue that the CK19 filament organization is defective in ES-derived cells, because of inappropriate intermediate filament association (or lack of intermediate filament associated proteins) due to insufficient or not optimal culture conditions. But, similar to the in vivo situation, CK19 is down regulated in ES-derived (C-peptide-positive) isletlike clusters at the terminal differentiation stage. Here, we firstly show that ES-derived pancreatic cells reveal at least, some functional properties of embryonic beta-like cells. The characteristic voltage-activated $\mathrm{Na}^{+}$channel inactivation (Göpel et al., 1999), voltage-activated $\mathrm{K}^{+}$channel properties and the $\mathrm{Ca}^{2+}$-dependent secretory activity in ES-derived pancreatic cells suggest a similar excitability of ES-derived pancreatic cells compared to embryonic beta-cells. These cells additionally are characterized by the presence of $\mathrm{K}_{\mathrm{ATP}}$ channels (Ashcroft and Rorsman, 1989) that were found in Pax4+, but not in wt cells. These and the other properties of ES-derived pancreatic islet-like clusters, such as partial expres- 
TABLE 3

\section{ELECTROPHYSIOLOGICAL PARAMETERS OF WT AND PAX4+ ES-DERIVED CELLS (N=16) FROM ISLET-LIKE CLUSTERS AT STAGE 5+30d}

\begin{tabular}{|c|c|c|c|c|c|c|c|c|}
\hline \multirow[t]{2}{*}{ Parameter } & \multicolumn{2}{|c|}{ Wt cells } & \multicolumn{2}{|c|}{ Pax4+cells } & \multirow{2}{*}{$\frac{\mathrm{t} \text {-test }}{\mathrm{P} \geq}$} & \multicolumn{2}{|c|}{ embryonic $\beta$-cells } & \multirow{2}{*}{$\frac{\text { adult } \beta \text {-cell }}{\text { amplitude }}$} \\
\hline & amplitude & $\mathbf{n}$ & amplitude & $\mathbf{n}$ & & amplitude & $\mathbf{n}$ & \\
\hline Cell capacitance $(\mathrm{pF})$ & $4.7 \pm 0.6$ & 14 & $6.7 \pm 0.9$ & 11 & 0.08 & $3.63 \pm 0.33$ & 10 & $7.4 \pm 0.3$ \\
\hline Vm (start) (mV) & $-37.8 \pm 3.2$ & 12 & $-39.9 \pm 2.8$ & 14 & 0.61 & $-50.5 \pm 7.6$ & 6 & $-60 /-80$ \\
\hline $\mathrm{Na}^{+}$current $(\mathrm{pA})$ & $-1310 \pm 511$ & $6 / 15$ & $-938 \pm 317$ & $7 / 11$ & 0.42 & $-365 \pm 31$ & $4 / 9$ & $-392 \pm 10$ \\
\hline Half inact. $\mathrm{Na}^{+}(\mathrm{mV})$ & $-86.0 \pm 5.1$ & $5 / 6$ & $-84.2 \pm 4.1$ & $5 / 7$ & 0.28 & $-100 \pm 7$ & 4 & $-104 \pm 1$ \\
\hline $\mathrm{K}^{+}$steady $(\mathrm{pA})$ & $+508 \pm 70$ & $13 / 16$ & $+598 \pm 106$ & $14 / 16$ & 0.34 & $1176 \pm 156$ & 8 & +950 \\
\hline Gap-junction conductance (nS) & $1.6 \pm 0.2$ & $5 / 5$ & $1.6 \pm 0.4$ & $4 / 5$ & 0.89 & $0.9 \pm 0.3$ & 9 & $1.4 \pm 0.2$ \\
\hline $\mathrm{K}_{\text {ATP }}$ conductance $(\mathrm{nS})$ & & $0 / 5$ & $0.28 \pm 0.06$ & $3 / 5$ & & $1.78 \pm 0.50$ & 9 & 2.6 \\
\hline Diazoxide ind. $\Delta \mathrm{Vm}(\mathrm{mV})$ & -13 & $1 / 5$ & $-12.5 \pm 2.1$ & $4 / 5$ & & $38.7 \pm 5.6$ & $5 / 5$ & \\
\hline Capacitance (fF) & 48 & $1 / 15$ & $170 \pm 95$ & $3 / 13$ & & $30 \pm 5$ & $4 / 6$ & $165 \pm 39$ \\
\hline
\end{tabular}

Each value represents mean \pm SEM. Statistical significance was tested by the Student T-test. The values reported for embryonic beta-cells are from Meneghel-Rozzo et al. (2004). The values for adult beta-cells are from Göpel et al. (1999) and Speier and Rupnik (2003). monothioglycerol [see (Wobus et al., 2002)] and cultured for 9 days. At day $5+9$, EB outgrowths were dissociated by $0.1 \%$ trypsin (Gibco): $0.08 \%$ EDTA (Sigma, Germany) in PBS (1:1) for 1 min, collected by centrifugation and re-plated onto poly-L-ornithine/ laminin-coated tissue culture dishes in "N2 medium + NA" containing DMEM/F12 (Gibco) supplemented by $20 \mathrm{nM}$ progesterone, 100 $\mu \mathrm{M}$ putrescine, $1 \mu \mathrm{g} / \mathrm{ml}$ laminin, $25 \mu \mathrm{g} / \mathrm{ml}$ insulin, $30 \mathrm{nM}$ sodium selenite, $10 \mathrm{mM}$ nicotinamide (NA) (all from Sigma), $50 \mu \mathrm{g} / \mathrm{ml}$ transferrin, $5 \mu \mathrm{g} / \mathrm{ml}$ fibronectin, B27 media supplement (dilution 1:50) (all from Gibco) and 15\% FCS. At day 5+10, the medium was changed and cells were cultivated in the differentiation medium without FCS until stages of analysis.

\section{Immunofluorescence analysis}

ES-derived cells growing on cover slips were fixed by $4 \%$ paraformaldehyde in PBS sion of CK19 and relatively low insulin levels, demonstrate that the cells are comparable to embryonic beta cells and do not represent definitive islet cells. This would be in agreement with recent data of quantitative gene expression levels in ES-derived hepatocyte-like cells that corresponded to a fetal developmental stage (Jochheim et al., 2004). The rescue of the diabetic phenotype by differentiated Pax4+ cells indicates that ES cells expressing Pax4 have the potential to function as beta-like cells. The higher efficiency of Pax4+ cells in vivo corresponds to the in vitro electrophysiological properties showing that $\mathrm{Pax} 4+$ cells represent a higher maturation stage in comparison to wt cells. Because also three other independently transfected Pax4+ clones showed increased insulin synthesis (unpublished data), we exclude clonal variation as explanation for the improved functional capacity of Pax4+ cells. Since there was a delay in blood glucose improvement for two weeks after transplantation, we speculate that in vivo, engrafted cells would mature further into a more functional cell type with physiological properties comparable to beta-like cells. Such in vivo maturation has been also observed in porcine neonatal pancreatic cell clusters transplanted into diabetic mice (Omer et al., 2003). In the future, a more detailed characterization of the transplanted cells will be necessary to assess the influence of the in vivo environment on the maturation of insulin-producing cells.

In summary, our model represents a new strategy to generate pancreatic progenitor and early pancreatic endocrine cells by a procedure that avoids all selection steps, which might critically affect ES cell differentiation into insulin-producing cells. Our in vitro differentiation protocol allows the investigation of genetic and epigenetic modifications in ES cells as well as the analysis of differentiation factors and signalling mechanisms necessary for the generation and maturation of pancreatic progenitors in vitro.

\section{Materials and Methods}

\section{Cell culture and differentiation conditions}

ES cells of line R1 (wild type, wt) and cells constitutively expressing Pax4 (Pax4+) were cultured as described (Wobus et al., 2002; Blyszczuk et al., 2003). Cells were differentiated in embryoid bodies (EBs, $600 \mathrm{ES}$ cells/EB) using the "hanging drop" method (Wobus et al., 2002). At day 5, EBs were plated in Iscove's modified Dulbecco's medium (IMDM, Gibco, Germany) supplemented with $20 \%$ FCS, L-glutamine, non-essential amino acids and $\alpha$ - for 20 minutes at room temperature and with methanol: acetone $(7: 3)$ for 10 minutes at $-20^{\circ} \mathrm{C}$, respectively and processed for immunofluorescence analysis as described (Wobus et al., 2002). Hoechst $33342(5 \mu \mathrm{g} / \mathrm{ml}, 10$ minutes, $37^{\circ} \mathrm{C}$ ) was used to label the nuclei. The following primary antibodies and dilutions were used: guinea pig IgG anti-C-peptide (Linco, USA) 1:100, mouse IgG anti-nestin (Developmental Studies Hybridoma Bank, USA) 1:3, rabbit IgG anti-desmin (Dako, Denmark) 1:100, mouse IgM anti-cytokeratin19 (Cymbus, UK) 1:100, rabbit lgG anti-Isl-1 (Abcam, UK) 1:200, rabbit lgG anti-carbonic anhydrase II (Abcam) 1:200 and mouse IgG anti-insulin (Sigma) 1:40. The following secondary antibodies were used according to the manufacturer's recommendations: FITC anti-mouse IgG, Cy3 anti-mouse IgG, Cy3 anti-mouse IgM, FITC anti-mouse IgG, FITC anti-guinea pig IgG, FITC anti-mouse IgG, FITC anti-rabbit IgG, Cy3 anti-rabbit IgG (all from Jackson ImmunoResearch Laboratories, USA). Samples were analysed by the fluorescence microscope ECLIPSE TE300 (Nikon, Japan) and the confocal laser scanning microscope LSM 510 META (Carl Zeiss, Germany). For quantitative evaluation of each experiment, at least 1000 Hoechstpositive cells were analysed.

\section{RT-PCR analysis}

Cells were suspended in lysis buffer ( $4 \mathrm{M}$ guanidinium thiocyanate, $25 \mathrm{mM}$ sodium citrate, $\mathrm{pH} 7 ; 0.5 \%$ sarcosyl, $0.1 \mathrm{M} \beta$-mercaptoethanol). Total RNA was isolated by the single step extraction method according to (Chomczynski and Sacchi, 1987). mRNA was reverse transcribed using PolyT tail primer Oligo $d(T)_{16}$ (PerkinElmer, Überlingen, Germany) and cDNA was amplified using the following primers: (name of the analysed gene, forward and reverse primer sequence and the length of the amplified fragment are given): $C K 19$ 5'-ctg cag atg act tca gaa cc-3', 5'-ggc cat gat ctc ata ctg ac-3', 299 bp; IAPP, 5'-tga tat tgc tgc ctc gga cc-3', 5'-gga gga ctg gac caa ggt tg-3', 233 bp; insulin, 5'-gtggatgcgcttcctgcccctg-3', 5'-atg ctg gtg cag cac tga-3', 288 bp; nestin 5'cta cca gga gcg cgt ggc-3', 5'-tcc aca gcc agc tgg aac tt-3', 220 bp; Pax4, 5'acc aga gct tgc act gga ct-3', 5'-cccattcagcttctcttgc-3' 300 bp; $P d \times 1,5^{\prime}$-ctt tcc cgt gga tga aat cc-3', 5'-gtc aag ttc aac atc act gcc-3', 230 bp; $\beta$-tubulin, 5'tca ctg tgc ctg aac tta cc-3', 5'-gga aca tag ccg taa act gc-3' 317 bp.

One third of each PCR reaction was electrophoretically separated on $2 \%$ agarose gels containing $0.35 \mu \mathrm{g} / \mathrm{ml}$ of ethidium bromide. Gels were illuminated with UV light and the ethidium bromide fluorescence signals of gels were stored by the E.A.S.Y. system (Herolab $\mathrm{GmbH}$, Wiesloch, Germany).

\section{Electrophysiological measurements}

The electrophysiological methods used were similar to those described for primary pancreatic tissue slices (Speier and Rupnik, 2003). Clusters at stage $5+30 \mathrm{~d}$ were resuspended into low gelling point agarose (Seaplaque GTG agarose, BMA, Walkersville, MD, USA; $1.9 \% \mathrm{w} / \mathrm{v}$ in extracellular 
solution), cooled and sliced in ice-cold solution using a vibratome (VT 1000 $\mathrm{S}$, Leica, Nussloch, Germany). The slices, $100 \mu \mathrm{m}$ thick, were stored at room temperature in extracellular solution bubbled with carbogen $\left(95 \% \mathrm{O}_{2}, 5 \%\right.$ $\mathrm{CO}_{2}$ ). Standard whole-cell patch-clamp was used in current- and in voltageclamp mode to measure the following electrophysiological parameters: membrane potential and membrane capacitance, currents through voltageactivated $\mathrm{Na}^{+}$and $\mathrm{K}^{+}$channels and ATP-sensitive $\mathrm{K}^{+}\left(\mathrm{K}_{\text {ATP }}\right)$ channels. Glucose $(20 \mathrm{mM})$ and classical agonists and antagonists of insulin secretion [tolbutamide $(100 \mathrm{uM})$ and diazoxide $(200 \mu \mathrm{M})$ ] were used to modify the electrical properties of the cells. A patch-clamp lock-in amplifier (SWAM II, Celica, Ljubljana, Slovenia) operating at $1.6 \mathrm{kHz}$ lock-in frequencies was used. Data were transferred to a PC via an A/D converter (PCl-6035E, National Instruments, Austin, Tex., USA) and acquired by WinWCP software (John Dempster, University of Strathclyde, UK). Borosilicate glass capillaries (GC150F-15; WPI, Sarasota, Fla., USA) were pulled (P-97; Sutter Instruments, Novato, CA, USA) to a resistance of 3-4M $\mathrm{M}$ in our pipette solution. During patch-clamp experiments, the slices were superfused at $35^{\circ} \mathrm{C}$ with extracellular solution and held on the bottom of the recording chamber by a platinum-frame with nylon fibre. The perfusion chamber was mounted on an inverted microscope (40w, NA 0.8 and 60w, NA 1.0, Eclipse E600FN; Nikon, Japan). The extracellular solution contained (in mM): $125 \mathrm{NaCl}, 2.5 \mathrm{KCl}, 1.25$ $\mathrm{NaH}_{2} \mathrm{PO}_{4}, 26 \mathrm{NaHCO}_{3}$, $2 \mathrm{Na}$-pyruvate, 0.5 ascorbic acid, 3 myo-inositol, 5 lactic acid, $1 \mathrm{MgCl}_{2}, 2 \mathrm{CaCl}_{2}, 3$ glucose. The pipette solution contained (in $\mathrm{mM}): 150 \mathrm{KCl}, 10 \mathrm{HEPES}, 2 \mathrm{MgCl}_{2} \times 6 \mathrm{H}_{2} \mathrm{O}, 0.05 \mathrm{EGTA}, 2 \mathrm{ATPNa}_{2}, \mathrm{pH} 7.2$ (adjusted with $\mathrm{KOH}$ ) (all from Sigma).

\section{Quantitative insulin determination by ELISA}

To estimate total cellular and secreted insulin levels, differentiated wt and Pax4+ cells were pre-incubated for 90 minutes at $37^{\circ} \mathrm{C}$ in Krebs Ringer Bicarbonate Hepes (KRBH) buffer containing $118 \mathrm{mM}$ sodium chloride, 4.7 $\mathrm{mM}$ potassium chloride, $1.1 \mathrm{mM}$ potassium dihydrogen phosphate, $25 \mathrm{mM}$ sodium hydrogen carbonate (all from Carl Roth), $3.4 \mathrm{mM}$ calcium chloride (Sigma), $2.5 \mathrm{mM}$ magnesium sulphate (Merck, Germany), $10 \mathrm{mM}$ Hepes (Gibco) and $2 \mathrm{mg} / \mathrm{ml}$ bovine serum albumin (Gibco) supplemented with 2.5 $\mathrm{mM}$ glucose. For induced insulin release, cells were further incubated in KRBH buffer supplemented with $27.7 \mathrm{mM}$ glucose and alternatively with 5.5 $\mathrm{mM}$ glucose and $10 \mu \mathrm{M}$ tolbutamide (Sigma) for 15 minutes at $37^{\circ} \mathrm{C}$. The control was incubated with $5.5 \mathrm{mM}$ glucose. Proteins were extracted from the cells with acid ethanol at $4^{\circ} \mathrm{C}$ overnight, followed by cell sonification. Determination of cellular and secreted insulin was performed using an insulin ELISA kit (Mercodia AB, Sweden). Protein was determined by the Bradford assay (Bio-Rad).

\section{Transplantation into Streptozotocin (STZ) induced diabetic mice}

Transplantations were essentially carried out as described (Blyszczuk et al., 2003). In brief, 8-10 week old male BALB/c mice ( $n=25$ each for wt and Pax4+ cells, $n=14$ for sham transplantation) were treated with a single i.p. injection of $200 \mathrm{mg} / \mathrm{kg}$ body weight STZ (Sigma). The diabetic status was determined by the presence of weight loss, polyuria and hyperglycaemia. For surgery, mice were anaesthetized with avertin (2.5\% in PBS, $15 \mu \mathrm{l} / \mathrm{g}$ body weight). Through a lumbar incision, the left kidney and the spleen were exposed. Using a blunt $30 \mathrm{~g}$-needle, approximately $4-6 \times 10^{6}$ cells were injected under the kidney capsule and into the spleen. Alternatively, culture medium was applied for sham transplants as control. Non-fasted blood glucose levels were measured between 8:00 and 10:00 a.m. using a OneTouch glucometer. For unilateral nephrectomy, the ureter and all vessels connecting to the left kidney were ligated using 5-0 size suture and the whole kidney was removed from the anaesthetized animal. After 39 days, $n=10$ Pax4+-cell-transplanted animals were alive. Out of these, 5 mice responded to transplantation with a normalization of blood glucose levels, as shown in Fig. 6 . In contrast, from $n=11$ surviving mice that were transplanted with wt cells and $n=8$ surviving sham-transplanted mice, none showed improvement of blood glucose levels. Mice of each of these control groups $(n=6)$ were chosen on the basis of comparable hyperglycaemic status prior to transplantation.

\section{Acknowledgements}

We would like to thank O. Weiss, D. Schrader, S. Sommerfeld, K. Meier and $S$. Kappler for excellent technical assistance. We are grateful to Dr. A. Rolletschek and C. Wiese (IPK Gatersleben) for helpful suggestions regarding differentiation conditions, to Drs. R. Wehr and M. Austen (DeveloGen AG, Göttingen) for support of the transplantation experiments and to Dr. K. Zaret (Philadelphia, PA, USA) for helpful comments. The work was financially supported by the EU grant Growbeta QLG1-CT-200102233, the Max-Planck-Society (to A.R. and M.R.); and the Deutsche Forschungsgemeinschaft (DFG, WO 503/3-2), the Bundesministerium für Bildung, Wissenschaft und Forschung (BMBF, 01GN0106), Fonds der Chemischen Industrie (FCI) and DeveloGen AG, Göttingen, Germany (to A.M.W).

\section{References}

AHLGREN, U., JONSSON, J., JONSSON, L., SIMU, K. and EDLUND, H. (1998). Beta-cell-specific inactivation of the mouse Ipf1/Pdx1 gene results in loss of the beta-cell phenotype and maturity onset diabetes. Genes Dev. 12: 1763-1768.

AHLGREN, U., PFAFF, S.L., JESSELL, T.M., EDLUND, T. and EDLUND, H. (1997). Independent requirement for ISL1 in formation of pancreatic mesenchyme and islet cells. Nature 385: 257-260.

ASHCROFT, F.M. and RORSMAN, P. (1989). Electrophysiology of the pancreatic beta-cell. Prog. Biophys. Mol. Biol. 54: 87-143.

ASSADY, S., MAOR, G., AMIT, M., ITSKOVITZ-ELDOR, J., SKORECKI, K.L. and TZUKERMAN, M. (2001). Insulin production by human embryonic stem cells. Diabetes 50: 1691-1697.

BLYSZCZUK, P., CZYZ, J., KANIA, G., WAGNER, M., ROLL, U., ST-ONGE, L. and WOBUS, A.M. (2003). Expression of Pax4 in embryonic stem cells promotes differentiation of nestin-positive progenitor and insulin-producing cells. Proc. Natl. Acad. Sci. USA 100: 998-1003.

BONNER-WEIR, S., TANEJA, M., WEIR, G.C., TATARKIEWICZ, K., SONG, K.H., SHARMA, A. and O'NEIL, J.J. (2000). In vitro cultivation of human islets from expanded ductal tissue. Proc. Natl. Acad. Sci. USA 97: 7999-8004.

BOUWENS, L. (1998). Cytokeratins and cell differentiation in the pancreas. J. Pathol. 184: $234-239$

BOUWENS, L., BRAET, F. and HEIMBERG, H. (1995). Identification of rat pancreatic duct cells by their expression of cytokeratins 7,19 and 20 in vivo and after isolation and culture. J. Histochem. Cytochem. 43: 245-253.

BOUWENS, L., LU, W.G. and DE KRIJGER, R. (1997). Proliferation and differentiation in the human fetal endocrine pancreas. Diabetologia 40: 398-404.

BREMBECK, F.H., MOFFETT, J., WANG, T.C. and RUSTGI, A.K. (2001). The keratin 19 promoter is potent for cell-specific targeting of genes in transgenic mice. Gastroenterology 120: 1720-1728.

CHIANG, M.K. and MELTON, D.A. (2003). Single-cell transcript analysis of pancreas development. Dev. Cell 4: 383-393.

CHOMCZYNSKI, P. and SACCHI, N. (1987). Single-step method of RNA isolation by acid guanidinium thiocyanate- phenol-chloroform extraction. Anal. Biochem. 162: 156-159.

CZYZ, J., WIESE, C., ROLLETSCHEK, A., BLYSZCZUK, P., CROSS, M. and WOBUS, A.M. (2003). Potential of Embryonic and Adult Stem Cells In Vitro. Biol. Chemistry 384: 1391-1409.

DELAcour, A., NEPOTE, V., TRUMPP, A. and HERRERA, P.L. (2004). Nestin expression in pancreatic exocrine cell lineages. Mech. Dev. 121: 3-14.

DOHRMANN, C., GRUSS, P. and LEMAIRE, L. (2000). Pax genes and the differentiation of hormone-producing endocrine cells in the pancreas. Mech. Dev. 92: 4754.

ESNI, F., STOFFERS, D.A., TAKEUCHI, T. and LEACH, S.D. (2004). Origin of exocrine pancreatic cells from nestin-positive precursors in developing mouse pancreas. Mech. Dev. 121: 15-25.

FEHMANN, H.C., WEBER, V., GOKE, R., GOKE, B. and ARNOLD, R. (1990). Cosecretion of amylin and insulin from isolated rat pancreas. FEBS Lett. 262:279281.

GITHENS, S., SCHEXNAYDER, J.A. and FRAZIER, M.L. (1992). Carbonic anhydrase II gene expression in mouse pancreatic duct cells. Pancreas 7: 556-561. 
GÖPEL, S., KANNO, T., BARG, S., GALVANOVSKIS, J. and RORSMAN, P. (1999). Voltage-gated and resting membrane currents recorded from B-cells in intact mouse pancreatic islets. J. Physiol $521 \mathrm{Pt} 3$ : 717-728.

HANSSON, M., TONNING, A., FRANDSEN, U., PETRI, A., RAJAGOPAL, J., ENGLUND, M.C., HELLER, R.S., HAKANSSON, J., FLECKNER, J., SKOLD, H.N., MELTON, D., SEMB, H. and SERUP, P. (2004). Artifactual insulin release from differentiated embryonic stem cells. Diabetes 53: 2603-9.

HERRMANN, H. and AEBI, U. (2000). Intermediate filaments and their associates: multi-talented structural elements specifying cytoarchitecture and cytodynamics. Curr. Opin. Cell Biol. 12: 79-90.

HORI, Y., RULIFSON, I.C., TSAI, B.C., HEIT, J.J., CAHOY, J.D. and KIM, S.K. (2002). Growth inhibitors promote differentiation of insulin-producing tissue from embryonic stem cells. Proc. Natl. Acad. Sci. USA 99: 16105-16110.

HUMPHREY, R.K., BUCAY, N., BEATTIE, G.M., LOPEZ, A., MESSAM, C.A., CIRULLI, V. and HAYEK, A. (2003). Characterization and Isolation of Promoter-Defined Nestin-Positive Cells from the Human Fetal Pancreas. Diabetes 52: 2519-2525.

HUNZIKER, E. and STEIN, M. (2000). Nestin-expressing cells in the pancreatic islets of Langerhans. Biochem. Biophys. Res. Commun. 271: 116-119.

JOCHHEIM, A., HILLEMANN, T., KANIA, G., SCHARF, J., ATTARAN, M., MANNS, M.P., WOBUS, A.M. and OTT, M. (2004). Quantitative gene expression profiling reveals a fetal hepatic phenotype of murine ES-derived hepatocytes. Int. J. Dev. Biol. 48: 23-29.

JONSSON, J., CARLSSON, L., EDLUND, T. and EDLUND, H. (1994). Insulinpromoter-factor 1 is required for pancreas development in mice. Nature 371: 606609.

KANIA, G., BLYSZCZUK, P., CZYZ, J., NAVARRETE-SANTOS, A. and WOBUS, A.M. (2003). Differentiation of mouse embryonic stem cells into pancreatic and hepatic cells. Methods in Enzymology 365: 287-303.

KLEIN, T., LING, Z., HEIMBERG, H., MADSEN, O.D., HELLER, R.S. and SERUP, P. (2003). Nestin is expressed in vascular endothelial cells in the adult human pancreas. J. Histochem. Cytochem. 51: 697-706.

LARDON, J., ROOMAN, I. and BOUWENS, L. (2002). Nestin expression in pancreatic stellate cells and angiogenic endothelial cells. Histochem. Cell Biol. 117: 535-540.

LEE, S.H., LUMELSKY, N., STUDER, L., AUERBACH, J.M. and MCKAY, R.D. (2000). Efficient generation of midbrain and hindbrain neurons from mouse embryonic stem cells. Nat. Biotechnol. 18: 675-679.

LEON-QUINTO, T., JONES, J., SKOUDY, A., BURCIN, M. and SORIA, B. (2004). In vitro directed differentiation of mouse embryonic stem cells into insulin-producing cells. Diabetologia 47: 1442-1451.

LUMELSKY, N., BLONDEL, O., LAENG, P., VELASCO, I., RAVIN, R. and MCKAY, R. (2001). Differentiation of embryonic stem cells to insulin-secreting structures similar to pancreatic islets. Science 292: 1389-1394.

MENEGHEL-ROZZO, T., ROZZO, A., POPPI, L. and RUPNIK, M. (2004). In vivo and in vitro development of mouse pancreatic beta-cells in organotypic slices. Cell Tissue Res. 316: 295-303.

MIYAZAKI, S., YAMATO, E. and MIYAZAKI, J. (2004). Regulated expression of pdx1 promotes in vitro differentiation of insulin-producing cells from embryonic stem cells. Diabetes 53: 1030-1037.

MORITOH, Y., YAMATO, E., YASUI, Y., MIYAZAKI, S. and MIYAZAKI, J. (2003). Analysis of insulin-producing cells during in vitro differentiation from feeder-free embryonic stem cells. Diabetes 52: 1163-1168.

OMER, A., DUVIVIER-KALI, V.F., TRIVEDI, N., WILMOT, K., BONNER-WEIR, S. and WEIR, G.C. (2003). Survival and maturation of microencapsulated porcine neonatal pancreatic cell clusters transplanted into immunocompetent diabetic mice. Diabetes 52: 69-75.

PARKKILA, A.K., SCARIM, A.L., PARKKILA, S., WAHEED, A., CORBETT, J.A. and SLY, W.S. (1998). Expression of carbonic anhydrase $V$ in pancreatic beta cells suggests role for mitochondrial carbonic anhydrase in insulin secretion. J. Biol. Chem. 273: 24620-24623.
PRAHLAD, V., YOON, M., MOIR, R.D., VALE, R.D. and GOLDMAN, R.D. (1998) Rapid movements of vimentin on microtubule tracks: kinesin-dependent assembly of intermediate filament networks. J. Cell Biol. 143: 159-170.

RAJAGOPAL, J. ANDERSON, W.J., KUME, S., MARTINEZ, O.I. and MELTON, D.A (2003). Insulin staining of ES cell progeny from insulin uptake. Science 299: 363.

RAMIYA, V.K., MARAIST, M., ARFORS, K.E., SCHATZ, D.A., PECK, A.B. and CORNELIUS, J.G. (2000). Reversal of insulin-dependent diabetes using islets generated in vitro from pancreatic stem cells. Nat. Med. 6:278-282.

ROHWEDEL, J., GUAN, K., HEGERT, C. and WOBUS, A.M. (2001). Embryonic stem cells as an in vitro model for mutagenicity, cytotoxicity and embryotoxicity studies: present state and future prospects. Toxicol. In Vitro 15: 741-753.

ROLLETSCHEK, A., CHANG, H., GUAN, K., CZYZ, J., MEYER, M. and WOBUS, A.M. (2001). Differentiation of embryonic stem cell-derived dopaminergic neurons is enhanced by survival-promoting factors. Mech. Dev. 105: 93-104.

SEABERG, R.M., SMUKLER, S.R., KIEFFER, T.J., ENIKOLOPOV, G., ASGHARZ., WHEELER, M.B., KORBUTT, G. and VAN DER KOOY, D. (2004). Clonal identification of multipotent precursors from adult mouse pancreas that generate neural and pancreatic lineages. Nat. Biotechnol. 22: 1115-1124.

SELANDER, L. and EDLUND, H. (2002). Nestin is expressed in mesenchymal and not epithelial cells of the developing mouse pancreas. Mech. Dev. 113: 189-192.

SIPIONE, S., ESHPETER, A., LYON, J.G., KORBUTT, G.S. and BLEACKLEY, R.C (2004). Insulin expressing cells from differentiated embryonic stem cells are not beta cells. Diabetologia 47: 499-508.

SORIA, B., ROCHE, E., BERNA, G., LEON-QUINTO, T., REIG, J.A. and MARTIN, F. (2000). Insulin-secreting cells derived from embryonic stem cells normalize glycemia in streptozotocin-induced diabetic mice. Diabetes 49: 157-162.

SORIA, B. (2001). In-vitro differentiation of pancreatic beta-cells. Differentiation 68 : 205-19.

SOSA-PINEDA, B., CHOWDHURY, K., TORRES, M., OLIVER, G. and GRUSS, P. (1997). The Pax4 gene is essential for differentiation of insulin-producing beta cells in the mammalian pancreas. Nature 386: 399-402.

SPEIER, S. and RUPNIK, M. (2003). A novel approach to in situ characterization of pancreatic beta-cells. Pflugers Arch. 446: 553-558.

STREET, C.N., LAKEY, J.R., SEEBERGER, K., HELMS, L., RAJOTTE, R.V., SHAPIRO, A.M. and KORBUTT, G.S. (2004). Heterogenous expression of nestin in human pancreatic tissue precludes its use as an islet precursor marker. $J$. Endocrinol. 180: 213-225.

WIESE, C., ROLLETSCHEK, A., KANIA, G., BLYSZCZUK, P., TARASOV, K.V., TARASOVA, Y.S., WERSTO, P., BOHELER, K.R. and WOBUS, A.M. (2004) Nestin expression - a property of multi-lineage progenitor cells? Cell. Mol. Life Sci. 61: $2510-2522$

WOBUS, A.M., GUAN, K., YANG, H.-T. and BOHELER, K.R. (2002). Embryonic stem cells as a model to study cardiac, skeletal muscle and vascular smooth muscle cell differentiation. In Methods in Molecular Biology, vol. 185: Embryonic Stem Cells: Methods and Protocols. K.Turksen, editor. Humana Press Inc., Totowa, NJ. 127 156.

ZULEWSKI, H., ABRAHAM, E.J., GERLACH, M.J., DANIEL, P.B., MORITZ, W., MULLER, B., VALLEJO, M., THOMAS, M.K. and HABENER, J.F. (2001). Multipotential nestin-positive stem cells isolated from adult pancreatic islets differentiate ex vivo into pancreatic endocrine, exocrine and hepatic phenotypes. Diabetes 50: $521-533$

Received: September 2004 Reviewed by Referees: October 2004 Modified by Authors and Accepted for Publication: November 2004 